\title{
A theory of operational cash holding, endogenous financial constraints, and credit rationing
}

\begin{abstract}
This paper develops a theory of operational cash holding. Liquidity shocks due to delayed payments must be financed using cash or short-term debt. Debt holders provide an irrevocable credit line given a firm's expected insolvency risk, and equity holders select optimum cash holding. The model demonstrates the trade-off between cash holding and investing in fixed assets. Introducing uncertain cashflows leads to precautionary cash holding if debt holders impose financial constraints. Precautionary cash holding, in turn, reduces insolvency risk enhancing access to short-term finance. The theory shows that credit rationing can occur in the absence of market frictions. Using U.S. data from 1998 to 2012, empirical findings suggest that the decline in credit lines has contributed to the increase in cash holding in line with theoretical predictions.

Keywords: cash holding, financial constraints, credit rationing, working capital management
\end{abstract}




\section{Introduction}

Cash ratios of U.S. companies more than doubled from $10.5 \%$ in 1980 to 23.2\% in 2006 (Bates et al., 2009) and have remained on high levels throughout the financial crisis. At the same time, recent discussions in the media stress that firms do not have sufficient access to bank finance, undermining the economic recovery. High levels of cash holding, credit rationing and lackluster investment seem to coexist, which is hard to comprehend drawing on established theories. For instance, investment opportunities should increase cash holding (Myers, 1977; Myers and Majluf, 1984). A theory that aims to explain this phenomenon has to derive optimum cash holding in the presence of endogenous financial constraints, and there needs to be a link between cash holding and investment. To isolate cash holding from other decisions such as capital structure, we focus on modeling short-term decisions during the cash conversion cycle (CCC) (Deloof, 2001; Gitman, 1974; Richards and Laughlin, 1980). In a short period of a few days, capital structure and dividends are fixed. This is consistent with Lins et al. (2010) who argue that most of the increase in cash holding is due to operational cash holding. Operational cash holding funds a firm's daily activities and is part of working capital management. Until recently, the literature has overlooked the im-

portance of working capital management. Jacobson and Schedvin (2015), Kling et al. (2014) and Kieschnick et al. (2013) provide empirical evidence, but a theory is missing. This paper proposes a theory of operational cash holding, endogenous financial constraints, and credit rationing. The paper tests theoretical predictions 
using U.S. data, uncovering the role of credit lines in understanding the increase in operational cash holding.

Theories have determined the demand for cash based on four motives: transaction, ${ }^{1}$ precaution, ${ }^{2}$ investment opportunities, and self-interest. ${ }^{3}$ Acharya et al. (2012) model the link between cash holding and credit risk, extending theories that do not capture financial constraints explicitly. For instance, Gryglewicz (2011) assumes constraint firms cannot raise additional capital after the initial stage, and Almeida et al. (2004) use proxies to classify companies. The three-period model developed by Acharya et al. (2012) derives precautionary cash holding in the presence of financial constraints, and Acharya et al. (2012) distinguish cash-flows from existing assets (labeled $x_{t}$ ), which are uncertain, and certain cash-flows from an investment project that can be financed only by cash since market frictions restrict access to external finance. Cash-flow risk is additive in that flows in period $t=1$ refer to a known constant $\bar{x}_{1}$ plus a random shock $u$ with $E(u)=0$. Thus, cash holding does not influence cash-flow risk. Acharya et al. (2012) derive precautionary cash holding as a buffer against negative cash-flows and a response to financial constraints.

The first contribution is to derive operational cash holding caused by a firm's short-term liquidity need, summarized in Theorem 1. The model follows Holm-

\footnotetext{
${ }^{1}$ Baumol (1952); Miller and Orr (1966).

${ }^{2}$ Keynes (1936) and recently Almeida et al. (2004); Gryglewicz (2011); Han and Qiu (2007); Riddick and Whited (2009).

${ }^{3}$ Self-interest leads to stockpiling of cash and value-destroying mergers (Graham and Harvey, 2001; Harford et al., 2008; Harford, 1999).
} 
ström and Tirole (1997) and Holmström and Tirole (1998) among others who view credit lines as pre-committed debt capacity. In the model, firms use credit lines to finance short-term liquidity needs and not long-term projects, as Lins et al. (2010) suggest. Banks often refer to "working capital lines of credit" (TCF Financial Corporation, Minnesota, USA), which best describes use of credit lines in the model. As Acharya et al. (2013) argue on p. 1, "Credit lines can be effective, and likely cheaper substitutes for corporate cash holding," and they are a substantial source of liquidity for U.S. firms (Sufi, 2009; Yun, 2009). However, Acharya et al. (2013) argue that revocations weaken commitment. In our model, firms cannot increase liquidity risk directly, and hence there is no 'illiquidity transformation,' which justifies revocations (Acharya et al., 2013).

The second contribution is to make financial constraints endogenous and demonstrate that firms can influence insolvency risk through cash holding (see Theorem 2). Denis and Sibilkov (2010) and Han and Qiu (2007) stress the importance of financial constraints, but established theories do not permit endogenous financial constraints (Acharya et al., 2012; Almeida et al., 2004; Denis and Sibilkov, 2010; Gryglewicz, 2011). In our model, cash holding has two effects: (1) the 'buffer effect' in line with Acharya et al. (2012) and (2) the risk-reduction effect since cash holding reduces fixed assets, limiting exposure to cash-flow risk. This finding reflects multiplicative instead of additive risk (Acharya et al., 2012). Multiplicative risk does not allow use of simple diffusion of cash-flows (e.g., Brownian Motion) applied by Gryglewicz (2011) as cash-flows are partly en- 
dogenous. Accordingly, the model focuses on a three-period context, which is sufficient to derive primary findings and consistent with the short-term view.

The third contribution is to demonstrate that credit rationing occurs in the absence of information asymmetry (see Theorem 3). Highlighted by Wolfson (1996), the predominant view in the literature is that information asymmetry causes credit rationing as shown by Stiglitz and Weiss (1981) and 'pure' credit rationing models that followed. Alternative explanations refer to asymmetric expectations (Wolfson, 1996), varying attitudes toward risk (Tobin, 1980), and covenant violations (Sufi, 2009; Yun, 2009). This paper suggests that credit rationing occurs in the absence of market frictions. Information is symmetric; expectations and attitudes toward risk do not differ among debt and equity holders. We contribute to earlier work reviewed by Baltensperger (1978), which derives credit rationing without resorting to market frictions (Jaffee and Modigliani, 1969).

\section{The Model}

\subsection{Model structure and assumptions}

Figure 1 illustrates the three-period structure with interim point, which follows Holmström and Tirole (1998) and Holmström and Tirole (2000). Our model is set in a frictionless environment (e.g. no taxes), and we make the following assumptions.

A-1 Equity and debt holders are risk-neutral.

A-2 Debt and equity holders are price-takers.

A-3 There are no agency costs. 
A-4 The discount rate from $t=0$ to $t=2$ is zero.

A-5 Net working capital, $\tilde{w}$, is uniformly distributed with $\tilde{w} \sim U(\underline{w}, \bar{w})$.

A-6 The cost-income ratio, $\tilde{k}$, is uniformly distributed with $\tilde{k} \sim U(0, \bar{k})$.

A-7 Net working capital, $\tilde{w}$, and the cost-income ratio, $\tilde{k}$, are independent.

A-8 Cash holding does not earn interest.

Debt holders behave like risk-averse agents due to their asymmetric payoff structure and A-1. A-2 implies that modeling the market structure such as in Jaffee and Modigliani (1969) extends beyond the scope of this paper. A-3 suggests that managers and equity holders maximize shareholder value. A-4 simplifies our model as we do not have to apply discount rates during the CCC. This is a plausible assumption given our short-term perspective. A-6 is relevant for modeling precautionary cash holding as we need to permit insolvency risk. A-7 simplifies our model. Robustness checks in section 3 relax assumptions A-5, A-6 and A-7, permitting a firm to exercise a degree of control over its net working capital, $w$. Finally, A-8 ensures consistency in line with A-4. We express all variables relative to total assets. By doing so, we model cash ratios defined as cash holding divided by total assets. This ensures that firm size (i.e. total assets $A$ ) does not affect optimal cash ratios directly.

\section{(Insert Figure 1)}

At $\mathrm{t}=0$, a new firm emerges with total assets, $A$, financed by equity and longterm debt. Debt holders form expectations about the firm's insolvency risk, $\pi$, and determine an irrevocable credit line, $s$, for a given interest rate, $r$. Equity holders 
observe the debt holder's choice and select a cash ratio, $c$, knowing the firm's parameters such as capital turnover, $T$, depreciation rate, $l$, long-term interest rates, $i$, and financial leverage, $L$. Only the proportion of total assets invested in fixed assets, $1-c$, generates cash-flows. Fixed assets produce revenue according to capital turnover, $T{ }^{4}$ The cost-income ratio, $k$, translates revenue into earnings before depreciation, $(1-c) T(1-k)$. We define costs only as operating costs (e.g. inputs, labor) and exclude any costs related to net working capital (e.g. interest expenses for using short-term finance). Fixed assets depreciate at rate $l$.

As the firm starts trading at $\mathrm{t}=0$, there is no initial net working capital, $w$. Equity holders are aware that an unknown liquidity need arises at $\mathrm{t}=1$ as some customers might not pay but some suppliers receive their payments. Hence, at $\mathrm{t}=1$, the firm experiences cash inflows, $R E V_{1}$, and outflows, $C O S_{1}$. The mismatch between outflows and inflows determines the short-term liquidity need $L I Q=C O S_{1}-R E V_{1}$ or expressed in terms of total assets $v=\frac{L I Q}{A}$, which requires financing through cash holding, $c$, and short-term debt, $s$. Liquidity default occurs if cash and credit lines are insufficient, i.e. $v>c+s$. In this case, equity holders receive a low residual claim, $\Theta$. At $\mathrm{t}=2$, the actual cost-income ratio, $k$, and net working capital, $w$, become public knowledge. We define net working capital, $w$, as accounts receivable, $A R$, minus accounts payable, $A P$, relative to total assets (i.e. $w=\frac{A R-A P}{A}$ ). Equity holders receive their residual claim if they can repay debt and interest. Otherwise, debt holders invoke an insolvency default.

\footnotetext{
${ }^{4}$ Considering a concave production function does not alter findings.
} 
With the CCC ending, all inflows and costs are realized so net working capital is zero. The residual claim refers to cash-flows, fixed assets after depreciation, and cash holding.

To distinguish between transaction and precautionary motives, we use two models. Model I assumes that cash flows over the whole period are certain, i.e. A-6 does not apply. The only uncertainty stems from the timing of cash flows, whether they occur at $t=1$ or at $t=2$. Model II permits uncertain cash flows. The following example illustrates Model I. We assume that the firm has total revenues, $R E V_{1}+R E V_{2}$, of 120 and total operating costs, $C O S_{1}+C O S_{2}$, of 100, excluding costs related to working capital management. Table 1 shows the timing of cash flows. Note that cash flows over the whole period are certain, and the cost-income ratio $k$ refers to total costs divided by total revenues over the whole period. The discount rate is zero based on A-4. In our example, the cost-income ratio is $k=$ $\frac{100}{120}=\frac{5}{6}$.

Table 1: Illustration of the model

\begin{tabular}{lrrrr}
\hline \hline Time & $t=0$ & $t=1$ & $t=2$ & period \\
\hline Revenues $R E V$ & - & 60 & 60 & 120 \\
Costs $C O S$ & - & 70 & 30 & 100 \\
\hline Net flow & - & -10 & 30 & 20 \\
\hline Accounts receivable $A R$ & - & 60 & - & - \\
Accounts payable $A P$ & - & 30 & - & - \\
\hline Net working capital & - & 30 & - & - \\
Liquidity need & - & 10 & - & - \\
\hline \hline
\end{tabular}

If cash outflows outweigh cash inflows at $\mathrm{t}=1$ a short-term liquidity need labeled $L I Q$ arises. Equation (1) defines the short-term liquidity need and links it 
to cash flows and net working capital defined as accounts receivable, $A R$ minus accounts payable $A P$. We then express the liquidity need in terms of total assets labeled $v$. Obviously, $A P_{1}=C O S_{2}$ and $A R_{1}=R E V_{2}$. Net working capital $w=\frac{A R_{1}-A P_{1}}{A}$ refers to deferred cash flows.

$$
\begin{aligned}
L I Q & =C O S_{1}-R E V_{1} \\
& =\left(C O S_{1}+C O S_{2}-A P_{1}\right)-\left(R E V_{1}+R E V_{2}-A R_{1}\right) \\
& =C O S_{1}+C O S_{2}-\left(R E V_{1}+R E V_{2}\right)+\left(A R_{1}-A P_{1}\right) \\
\Leftrightarrow \frac{L I Q}{A} & =v=w-T(1-k)
\end{aligned}
$$

By definition, the short-term liquidity need, $L I Q$, refers to cash outflows and inflows at $t=1$, which are equal to net working capital, $w$, minus total net cash flows over the whole period. Note that equity holders observe cash inflows, $R E V_{1}$, and outflows, $\operatorname{COS}_{1}$, at $\mathrm{t}=1$; hence, the short-term liquidity need $L I Q=\operatorname{COS}_{1}-$ $R E V_{1}$ is known. Only at $\mathrm{t}=2$, the actual cost-income ratio, $k$, and net working capital, $w$, are known and thus the underlying cause for the short-term liquidity need can be understood.

Apart from equation (1), we suppress subscripts for the three periods. First, A-4 applies so that the actual timing of the cash flow is not relevant for deriving net present values. Second, some variables such as the liquidity need, $v$, and net working capital, $w$, only occur at $\mathrm{t}=1$. Third, some variables refer to the whole period such as the cost-income ratio, $k$. 


\subsection{Model I: The transaction motive}

To identify the transaction motive, we deactivate A-6 making the cost-income ratio certain $(\tilde{k}=k)$, implying no cash-flow and insolvency risk. Consequently, debt holders provide short-term funding at the risk-free rate $\left(r=r_{f}\right) .^{5}$ From A-5 and equation (1), the short-term liquidity need is uniformly distributed with $\tilde{v} \sim U(\underline{v}, \bar{v})$ with $\underline{v}=\underline{w}-T(1-k)$ and $\bar{v}=\bar{w}-T(1-k))$. Furthermore, we assume that $c \geq 0 \geq \underline{w}-T(1-k)$. Equity holders maximize the expected utility $U_{E}(c)$ expressed in terms of total assets selecting optimal cash holding.

$$
U_{E}(c)=(1-c) T(1-k)-L(1+i)-(1-c) r \int_{c}^{\bar{v}} \frac{v-c}{\bar{w}-\underline{w}} d v+(1-c)(1-l)+c
$$

Equation (2) describes equity holders' expected residual claim; they receive total cash flows, $(1-c) T(1-k)$, repay long-term debt and interest, $L(1+i)$, and cover expected interest payments for using the credit line. Firms resort to shortterm debt only if the short-term liquidity need exceeds cash holding, captured by the partial expected value in (2). ${ }^{6}$ Short-term debt can be repaid since net working capital is zero at $\mathrm{t}=2$. The residual claim also includes fixed assets after deprecation and initial cash holding. Cash used to fund the short-term liquidity need is

\footnotetext{
${ }^{5}$ For maximum short-term debt $s$ and a firm without cash holding, $s r_{f}+L\left(1+r_{f}\right) \leq(1-$ $k) T$ implies no insolvency risk. This is the same condition as in proposition (1.3) in Jaffee and Modigliani (1969).

${ }^{6}$ We refer to Grüner and Zoller (1997), Landsman and Valdez (2005) and Winkler et al. (1972) for mathematical properties.
} 
repaid at $\mathrm{t}=2$. Equation (2) reveals the two effects of cash holding, being a buffer for short-term liquidity needs and determining the exposure to risk and reward through reducing invested capital. Theorem 1 derives optimum cash holding, and Appendix A provides a proof.

Theorem 1. (Transaction Cash) Equity holders select cash holding based on the transaction motive, $c_{T}^{*}$, since they face an uncertain short-term liquidity need due to exogenous shocks in net working capital, $\tilde{w}$.

$$
c_{T}^{*}=\frac{1+2 \bar{v}-\sqrt{(1-\bar{v})^{2}+\frac{6}{r}(T(1-k)-l)(\bar{w}-\underline{w})}}{3}
$$

Transaction cash is strictly positive, $c_{T}^{*}>0$, if the following condition holds.

$$
r>r_{\text {min }}=\frac{(T(1-k)-l)(\bar{w}-\underline{w})}{\frac{1}{2} \bar{v}^{2}+\bar{v}}
$$

Theorem 1 describes the trade-off between investing in fixed assets and cash holding, reflecting the transaction motive. Obviously, if net return on fixed assets is negative, $T(1-k)-l<0$, equity holders do not invest in fixed assets, and there is no need for short-term financing. Transaction cash, $c_{T}^{*}$, only occurs if interest rates, $r$, charged for using the credit line, are sufficiently high. Cash holding has two effects. It reduces expected costs of short-term borrowing and it reduces investment in fixed assets. The latter leads to a loss of net return on fixed assets, 
but also limits exposure to short-term liquidity shocks. This trade-off between cash holding and fixed assets is the primary difference compared to other models. ${ }^{7}$

\subsection{Model II: The precaution motive}

To explore precautionary cash holding, we activate A-6 and assume an uncertain cost-income ratio, $\tilde{k}$. Our approach differs from extant research in that cash-flows are only partly random since firms can modify cash-flow risk through cash holding (i.e., restricting the amount invested in fixed assets). So risk is multiplicative and not additive as in Acharya et al. (2012). The cost-income ratio is uniformly distributed with $k \sim U(0, \bar{k})$ (see A-6). The cost-income ratio is independent from net working capital ( $\tilde{w})$ (see A-7). Uncertain cash-flows imply insolvency risk, $\pi$, so debt holders might not be willing to offer an unlimited credit line, $s$, for a given cost of debt, $r$. Thus, the model considers the possibility of liquidity default at the interim point $t=1$ if the actual short-term liquidity need exceeds cash holding plus the credit line, $v>s+c$. In the case of liquidity default, shareholders receive $\Theta$. Later we set $\Theta=0$ to simplify the model. Based on equation (1) and A-7, Lemma 1 derives the density function of the short-term liquidity need $f_{\tilde{v}}(v)$.

Lemma 1. $f_{\tilde{v}}(v)$ is the convolution of $f_{\tilde{x}}(x)$ and $f_{\tilde{y}}(y)$, where $\tilde{x}=\tilde{w}-T \sim U(\underline{w}-$ $T, \bar{w}-T)$ and $\tilde{y}=T \tilde{k} \sim U(0, T \bar{k})$. Assuming that operating costs relative to total assets are smaller than the range of net working capital (i.e. $T \bar{k}<\bar{w}-\underline{w}$ ) provides

\footnotetext{
${ }^{7}$ Gryglewicz (2011) assumes debt and equity are selected such that a firm reaches desired cash holding and investment; a trade-off does not occur.
} 
the following result based on Killmann and von Collani (2001).

$$
f_{\tilde{v}}(v)=\left(f_{\tilde{x}} * f_{\tilde{y}}\right)(v)= \begin{cases}0 & \text { if } v<\underline{w}-T \\ \frac{v-\underline{w}+T}{(\bar{w}-\underline{w}) T \bar{k}} & \text { if } \underline{w}-T \leq v<\underline{w}-T+T \bar{k} \\ \frac{1}{\bar{w}-\underline{w}} & \text { if } \underline{w}-T+T \bar{k} \leq v<\bar{w}-T \\ \frac{-v+\bar{w}-T+T \bar{k}}{(\bar{w}-\underline{w}) T \bar{k}} & \text { if } \bar{w}-T \leq v \leq \bar{w}-T+T \bar{k} \\ 0 & \text { if } v>\bar{w}-T+T \bar{k}\end{cases}
$$

To evaluate expected costs of short-term finance, we need to consider thresholds of $f_{\tilde{v}}$ based on Lemma 1 that are positive because only if $v>0$ cash outflows outweigh inflows at $\mathrm{t}=1$, creating a financing need. Assuming that $\bar{w}<T$, i.e. the maximum net working capital relative to total assets is less than the capital turnover, which seems to be plausible for most firms, we can determine the expected costs of short-term finance. Furthermore, we assume that liquidity risk exists, implying $0 \leq s<\bar{w}-T+T \bar{k}$, so that $\bar{w}-T<c \leq v \leq c+s<\bar{w}-T+T \bar{k}$.

$$
\begin{aligned}
\int_{c}^{s+c}(v-c) f_{\tilde{v}}(v) d v & =\int_{c}^{s+c} \frac{-v+\bar{w}-T+T \bar{k}}{(\bar{w}-\underline{w}) T \bar{k}} d v \\
& =\frac{1}{(\bar{w}-\underline{w}) T \bar{k}}\left[-\frac{1}{2} v^{2}+\bar{w} v-T(1-\bar{k}) v\right]_{c}^{c+s} \\
& =\frac{-\frac{1}{2} s^{2}-c s+\bar{w} s-T(1-\bar{k}) s}{(\bar{w}-\underline{w}) T \bar{k}}
\end{aligned}
$$

Lemma 2 determines the critical cost-income ratio $k^{*}$ for insolvency default by setting equation (2) equal to or less than zero so that the entity value is insufficient 
to pay debt holders. We replace the upper limit of the short-term liquidity need, $\bar{v}$, with $s+c$, since this is the maximum amount available for short-term finance, the credit line and cash holding.

Lemma 2. The critical cost-income ratio $k^{*} \in[0, \bar{k}]$ for insolvency default is

$$
\begin{aligned}
k^{*} & =1-\frac{L(1+i)+(1-c) r \int_{c}^{s+c}(v-c) f_{\tilde{v}}(v) d v-1+l-l c}{(1-c) T} \\
& =1+\frac{1-L(1+i)}{(1-c) T}-\frac{r\left(-\frac{1}{2} s^{2}-c s+\bar{w} s-T(1-\bar{k}) s\right)}{(\bar{w}-\underline{w}) T^{2} \bar{k}}-\frac{l}{T}
\end{aligned}
$$

Using Lemma 2 and A-6, we define insolvency risk $\pi$.

$$
\pi=1-\int_{0}^{k^{*}} \frac{1}{\bar{k}} d k=1-\frac{k^{*}}{\bar{k}}
$$

Differentiating the critical cost-income ratio with respect to cash holding reveals the impact of cash holding on the critical cost-income ratio, which drives insolvency risk. Lemma 3 summarizes the partial impact of cash holding on insolvency risk, and Appendix B provides a proof.

Lemma 3. Cash holding increases the critical cost-income ratio, $k^{*}$, reducing insolvency risk, $\pi$, if financial leverage is below the critical level, $L_{\max }$.

$$
\frac{\partial \pi}{\partial c}<0 \quad \text { if } L<\frac{1}{1+i}+\frac{r s(1-c)^{2}}{(\bar{w}-\underline{w}) T \bar{k}(1+i)}=L_{\max }
$$

Cash holding is selected after the credit line is announced. Equity holders can regard the credit line as a known parameter in their optimization problem. Since 
it is a two-stage decision problem, we analyze the second stage first, and section 2.4 deals with the first stage. Equity holders do not consider insolvency risk, $\pi$, directly since they are risk-neutral with a linear payoff profile. The investment decision is based solely on the expected cost-income ratio, $E(k) .{ }^{8}$ Modifying equation (2) yields the following expected utility, which incorporates the possibility of liquidity default. ${ }^{9}$

$$
\begin{aligned}
U_{E}(c) & =[(1-c) T(1-E(\tilde{k}))-L(1+i)+1-l+l c]\left[1-\int_{s+c}^{\bar{w}-T+T \bar{k}} f_{v}(\tilde{v}) d v\right] \\
& -(1-c) r \int_{c}^{s+c}(v-c) f_{v}(\tilde{v}) d v+\Theta \int_{s+c}^{\bar{w}-T+T \bar{k}} f(\tilde{v}) d v
\end{aligned}
$$

Differentiating equation (5) with respect to cash holding leads to Theorem 2. Appendix C provides a detailed proof.

Theorem 2. (Precautionary cash holding) Precautionary cash holding occurs only if financial constraints are applied, $s+c<\bar{v}$. Optimum precautionary cash holding is

$$
c_{P}^{*}=\frac{2 \alpha(\bar{v}-s)+\alpha+\gamma+2 r s-\sqrt{(2 \alpha(\bar{v}-s)+\alpha+\gamma+2 r s)^{2}-6 \alpha \Omega}}{3 \alpha}
$$

\footnotetext{
${ }^{8}$ No investment occurs if $E(k)>k^{*}$.

${ }^{9}$ The partial expected value for short-term financing costs refers to the conditional expected value times the probability that the condition occurs (i.e., no liquidity default).
} 
where $\alpha=T\left(1-\frac{\bar{k}}{2}\right)-l>0, \beta=(\bar{w}-\underline{w}) T \bar{k}>0, \gamma=1-L(1+i)>0$ and $\Omega=\frac{\alpha}{2}(\bar{v}-s)^{2}+(\bar{v}-s)(\alpha+\gamma)+r s\left(\bar{v}-\frac{1}{2} s+1\right)-\alpha \beta>0$ are independent from $c$.

Theorem 2 shows that precautionary cash holding occurs if debt holders impose financial constraints such that $s+c<\bar{v}$. By restricting access to finance, debt holders force equity holders into liquidity risk. To mitigate liquidity risk, equity holders select precautionary cash holding, which reduces insolvency risk. Precautionary cash holding can be positive even if the interest rate on short-term finance is equal to zero, in contrast to cash holding motivated by the transaction motive. Based on Theorem 1, the price mechanism is unable to reduce demand for short-term financing as long as interest rates are not sufficiently high. Theorem 2 confirms that selecting optimum precautionary cash holding maximizes shareholder value and is therefore a rational choice for equity holders. The following section addresses the question of whether credit rationing, which leads to precautionary cash holding, is also a rational choice for the debt holder.

\subsection{The debt holders perspective and credit rationing}

After discussing equity holders' cash holding decision for a given credit line $s$, we turn to the first stage, optimum selection of the credit line $s$. If a firm survives, the debt holder receives a fixed payment of the principal and interest earned at $t=2$. If the firm is insolvent, the debt holder receives only a fraction of the claim, $0<\epsilon<1$, leading to a concave payout structure. The debt holder has an incentive to influence insolvency risk, $\pi$. Shown in Theorem 2, restricting access to shortterm financing, $s+c<\bar{v}$, forces a firm to hold cash, which reduces insolvency 
risk (see Lemma 3). We assume that the total short-term lending capacity in terms of total assets denoted $\bar{s}$ is sufficient to fund short-term liquidity needs, $\bar{s}>\bar{v}$. Furthermore, the debt holder provides short and long-term debt.

The debt holder maximizes the utility function, $U_{D}(s)$, by selecting optimum credit line, $s$. The debt holder has no market power, and thus is a price-taker. In line with A-4, we set the risk-free rate equal to zero, $r_{f}=0$.

$$
U_{D}(s)=(s(1+r)+L(1+i))(1-\pi)+(s+L) \pi \epsilon+\bar{s}-s
$$

We explore two cases: credit rationing does not occur, $s \geq \bar{v}(C A S E 1)$, and credit rationing occurs, $s<\bar{v}(C A S E 2)$. In CASE 1, precautionary cash holding does not exist and access to short-term financing is sufficient to cover the shortterm liquidity need; hence, there is no liquidity default. Theorem 2 does not apply, and as a consequence, the credit line does not influence cash holding or insolvency risk, $\frac{\partial \pi}{\partial s}=0$. Equity holders are not price sensitive as long as $r<r_{\min }$ (see Theorem 1). In fact, increasing the cost of debt increases insolvency risk since the critical cost-income ratio $k^{*}$ declines, $\frac{\partial \pi}{\partial r}>0$. The debt holder maximizes (6), and since $U_{D}(s)$ is linear in $s$, the optimum credit line follows a bang-bang solution. Credit rationing does not occur, i.e. $s^{*}=\bar{s}$, as long as cost of debt compensates for expected default risk, captured in condition (7). Since insolvency risk $\pi$ depends on cost of debt, there is no guarantee that (7) holds.

$$
r \geq \frac{\pi(r)(1-\epsilon)}{1-\pi(r)}
$$


CASE 2 considers the possibility of credit rationing through which a debt holder can influence insolvency risk (see Theorem 2). If $r<r_{\min }$, transaction cash is zero based on Theorem 1, and Lemma 3 confirms that cash holding reduces insolvency risk. In this case, we deduce from Theorem 2 that $\frac{\partial \pi}{\partial s}>0$. Hence, the debt holder considers her impact on insolvency risk when selecting the credit line. Under certain conditions derived in Appendix D, credit rationing is inevitable leading to Theorem 3 .

Theorem 3. (Credit Rationing) Credit rationing occurs if the following inequality holds, where $E_{0}^{\bar{\gamma}}(\tilde{v})$ denotes the partial expected value of the short-term liquidity need for positive values. In this case, a cost of debt, $r$ satisfying the debt holder's participation constraint does not exist.

$$
\frac{E_{0}^{\bar{\nu}}(\tilde{v})}{T \bar{k}}>\frac{(1-\pi)^{2}}{1-\epsilon}
$$

Theorem 2 and Lemma 3 show that credit rationing operates by providing incentives to equity holders to increase cash holding, which lowers insolvency risk. Theorem 1 highlights that equity holders are not price sensitive if the cost of debt is lower than $r_{\text {min }}$. Therefore, higher cost of debt does not lower insolvency risk but increases it. The latter point is important to demonstrate that credit rationing occurs when condition (7) is violated. Theorem 3 formalizes the condition and illustrates that firms with high expected liquidity needs $(E(\tilde{v}))$ and insolvency risk $(\pi)$ likely face credit rationing. Credit rationing is a rational choice for the debt holder. 


\section{Discussion of assumptions and robustness checks}

This section highlights robustness checks by relaxing model assumptions. Some assumptions such as A-1, A-2 and A-3 are important for limiting the scope of the theory, focusing our attention on short-term decisions taken by shareholder value maximizing decision makers. Risk-neutrality is convenient as it eliminates the need to specify a precise utility function, capturing decision makers appetite for risk. A-4 is plausible given the short-term view and simplifies the model. Introducing discount rates does not add additional insights. Conceptually, there might be a problem as cost of capital, if we include short-term finance, changes from $\mathrm{t}=0$ to $\mathrm{t}=2$.

Using uniform distributions such as in A-5 and A-6 is plausible if little is known about the risks the firm faces, except for worst case scenarios. In addition, uniform distributions allow closed-form solutions. Given our definition of the cost-income ratio, which excludes costs related to working capital management, independence suggested by A-7 between the cost-income ratio and net working capital is plausible. This assumption can be relaxed; however, at a high cost as Lemma 1 does not apply. A-8 is consistent with A-4 and in line with the shortterm perspective.

In reality, firms have some control over their net working capital so that A5 can be relaxed. For instance, accounts receivable can be converted into cash using factoring. Yet the extent of a firm's control depends on various factors, e.g. negotiating power and market structure. Therefore, firms can affect liquidity risk directly. This causes problems as outlined by Acharya et al. (2013) as 
'illiquidity transformation' can trigger revocations, making the credit line revocable. Modeling active working capital management (e.g. trade credit or inventory management) is beyond the scope of the paper.

\section{Empirical evidence}

\subsection{Data and definition of variables}

This section illustrates the relevance of the theory by extending Bates et al. (2009). The sample consists of constituents of the S\&P500 from 1990 to 2011. Companies included in the S\&P500 at any point during the investigation period were considered to avoid survivorship bias. Data on lines of credit $(s)$ are unavailable before 1998, expect for 12 firm-year observations in 1997 and fewer in previous years. Hence, we restrict the analysis to the period 1998 to 2012. Bloomberg provides data on the 930 companies, resulting in 9,332 firm-year observations of cash holding. Due to missing data concerning explanatory variables, the maximum number of observations in regressions was 5,405.

To re-estimate the models in Table III (p. 2001/2002) reported by Bates et al. (2009), we used the same variables. Cash holding was measured relative to total assets $(c)$ or as the log of cash holding divided by total assets ( $\log ($ Cash/Assets $))$. The first-difference in cash ratios indicated year-by-year changes (Changes). We included lagged cash ratios (Lag dcash) or lagged changes in cash ratios (Lag cash). We also considered volatility of cash-flows in the industry (Sigma), market-

to-book, firm size (Size), cash-flows relative to total assets (Cash-flow assets), net working capital relative to total assets (NWC assets), capital expenditure 
$(C A P E X)$, financial leverage (Leverage), $\mathrm{R} \& \mathrm{D}$ relative to sales ( $R D$ sales), a dummy variable for dividends (Div dummy), and acquisition activity ( $A C Q C$ ). Acquisition activity refers to net cash paid for acquisitions relative to total assets. We deviate from Bates et al. (2009) in that we use nominal values to determine the log of total assets. Using real values is less common in the literature.

Based on our theoretical model, we derive two propositions in line with Theorems 1 and 2. Proposition 1 focuses on the trade-off between cash holding and investment in fixed assets, whereas Proposition 2 explores the impact of credit rationing.

Proposition 1. There is a trade-off between cash holding and investing in fixed assets. Hence, net return on fixed assets has a negative and cost of debt has a positive partial impact on cash holding.

Proposition 2. Credit rationing leads to precautionary cash holding. Accordingly, the credit line and uncertainty in accessing finance have a negative partial impact on cash holding. Expected liquidity shortages increase precautionary cash holding.

To test our propositions, we added the following variables: expected net return on fixed assets (return) as defined in the theoretical model (i.e., $E(T(1-k)-l)){ }^{10}$ cost of bank finance $(r),{ }^{11}$ and credit line $(s)$. The model also incorporates the variation coefficient of the credit line as a proxy for the uncertainty of access to

\footnotetext{
${ }^{10} \mathrm{We}$ regressed net return on assets on lagged values and controlled for industry fixed-effects. Predicted values refer to expectations.

${ }^{11}$ We did not distinguish long- and short-term interest rates due to lack of data.
} 
short-term bank financing ( $v c s$ ). Variable E shortage measures the expected liquidity shortage based on past fluctuations in net working capital. The expected liquidity shortage refers to the probability that the short-term liquidity need exceeds the credit line, assuming a normal distribution $(\operatorname{Prob}(v>s)=1-F(s))$. This can be interpreted as a measure for credit rationing since $\operatorname{Prob}(v>s)>0 \Rightarrow$ $s<\bar{v}(v \in[\underline{v}, \bar{v}])$. All variables were winsorized at $1 \%$ and $99 \%$ percentiles to mitigate the impact of outliers.

\subsection{Empirical findings}

Table 2 shows descriptive statistics for all variables. The median and mean of expected net return on fixed assets (return) exceeded the median and mean of cost of debt $(r)$. Hence, Theorem 1 suggests that cash holding based on the transaction motive is unlikely since cost of debt is low. On average, firms had a credit line of $12 \%$ of total assets in comparison to average cash holding of $10 \%$ of total assets. Hence, credit lines were substantial. The probability that shortterm liquidity needs exceeded the credit line was, on average, 9\% (E shortage). Therefore, cash holding might be needed to fill the liquidity gap.

(Insert Table 2)

(Insert Figure 2)

Figure 2 plots average cash ratios $(c)$ and credit lines $(s)$ over time, revealing a steady decline in credit lines and pronounced increase in cash holding. It 
is conceivable that cash holding serves as a substitute for credit lines or that precautionary cash holding is needed to address short-term liquidity risk. Figure 2 indicates that liquidity shortfalls (E shortage) have stabilized over time.

Table 3 re-estimates models applied by Bates et al. (2009). All specifications refer to fixed-effects models, and Table 3 reports various measures of Rsquared (i.e., within, between, and overall), commensurate with fixed-effects models. Standard errors were robust to clustering to account for heteroskedasticity and autocorrelation. Most findings accorded with Bates et al. (2009). In line with the fixed-effects regression in Table III on p. 2002 reported by Bates et al. (2009), we confirmed that market-to-book and cash-flow to assets have a positive partial influence on cash ratios. We also found a negative coefficient for net working capital relative to total assets and CAPEX. Leverage is only significant if we consider the log cash ratio as a dependent variable. In most specifications, Bates et al. (2009) report a negative impact of firm size, consistent with our findings. The only surprising finding was the positive effect of acquisition. Bates et al. (2009) use the same definition and argue that more cash outflows to fund acquisitions reduce cash holding. In contrast, we revealed that acquisition led to an increase in the stockpile of cash, a finding in line with Graham and Harvey (2001), Harford et al. (2008), and Harford (1999).

\section{(Insert Table 3)}

Table 4 extends the model by incorporating additional variables suggested by the theory, using cash ratios $(c)$ as a dependent variable. The first model $(A 1)$ combines all additional explanatory variables, and subsequent models highlight 
individual impacts. As predicted, credit lines $(s)$ had a negative effect on cash holding, shown in models $(A 1)$ and $(D 1)$. Expected liquidity shortages did not influence cash holding. By construction, our measure of liquidity shortages correlates negatively with credit line. ${ }^{12}$ Model $(F 1)$ considered only E shortage, but failed to indicate a significant impact. The variation coefficient of credit lines $(v c s)$ did not explain cash ratios as reported in models $(A 1)$ and $(E 1)$.

\section{(Insert Table 4)}

Using the log cash ratio as a dependent variable led to similar results. Table 5 confirms a negative partial impact of credit line in models (A2) and (D2). In contrast to regressions with the cash ratio as a dependent variable (see Table 4), expected net returns on fixed assets (return) had a negative influence on cash holding, as predicted by Proposition 1.

\section{(Insert Table 5)}

Finally, the decline in credit lines explains the change in cash ratios (see models (A3) and (D3) in Table 6), supporting Proposition 2. The coefficient of expected net returns on fixed assets (return) was negative. The latter findings are consistent with a trade-off between holding-cash and investing in fixed assets, confirming Proposition 1.

(Insert Table 5)

\footnotetext{
${ }^{12}$ The correlation coefficient was -0.531 .
} 
Variables suggested by the theory improve the empirical models used by Bates et al. (2009). In fact, a likelihood ratio test rejects restricting model (A1) to the standard model used by Bates et al. (2009) with $L R \operatorname{chi}^{2}(6)$ of 64.29 and p-value of 0.000 . Proportion 1 and 2 can be confirmed. In particular, empirical findings point to precautionary cash holding and credit rationing as driving forces behind the recent increase in cash holding.

\section{Conclusion}

This paper develops a theory of operational cash holding and explores the links between short-term liquidity needs due to delayed payments, access to short-term finance, liquidity risk and insolvency risk. Operational cash holding aims to fund a firm's daily operations (Lins et al., 2010), and hence the paper takes a short-term view in the spirit of the literature on the cash conversion cycle (Gitman, 1974; Richards and Laughlin, 1980). In contrast to Acharya et al. (2012), Almeida et al. (2004), Denis and Sibilkov (2010), Denis and Sibilkov (2010), and Gryglewicz (2011) among others, the theory permits endogenous financial constraints. Cash holding influences cash-flow risk by restricting the amount invested in fixed assets, which leads to a multiplicative understanding of risk as opposed to additive risk (Acharya et al., 2012). Consequently, cash holding is a buffer - as in established theories - but also a lever, moderating cash-flow risk.

Model I demonstrates the trade-off between cash holding and investing in fixed assets. Theorem 1 reveals that firms are not price sensitive if cost of debt is be-

low the critical value, $r_{\min }$. Thus, the price mechanism fails to dampen demand 
for short-term finance. By introducing uncertain cash-flows, Model II shows that cash holding reduces insolvency risk (see Lemma 3). Since equity holders are risk-neutral and have a linear payoff profile, they do not internalize their influence on insolvency risk. Theorem 2 illustrates that credit rationing exposes equity holders to liquidity risk, and they respond by holding precautionary cash, which lowers insolvency risk. This mechanism does not require market frictions such as information asymmetry; it simply stems from the payoff structure of debt and equity holders. Theorem 3 illustrates that credit rationing is inevitable if the participation constraint (7) is violates. Theorem 3 generalizes to any setting in which insolvency risk depends on cost of debt, and cost of debt is the solution of the fixed point iteration $r_{n+1}=g\left(r_{n}\right)(n=1,2, \ldots)$. If $g\left(r_{n}\right)$ is not a contraction mapping, there is no cost of debt that compensates for insolvency risk, causing credit rationing. The theory contributes to earlier literature on credit rationing in the absence of market frictions (Baltensperger, 1978; Jaffee and Modigliani, 1969).

Two propositions capture theoretical predictions and are tested using U.S. data from 1998 to 2012. Empirical findings confirm theoretical predictions. In particular, the steady decline in credit lines has contributed to the increase in cash holding. We stress that our theoretical model should be re-tested by other researchers. 


\section{References}

Acharya, V., Almeida, H., Ippolito, F., Perez, A., 2013. Credit lines as monitored liquidity insurance: Theory and evidence.

Acharya, V., Davydenko, S., Strebulaev, I., 2012. Cash holdings and credit risk. Review of Financial Studies 25, 3572-3609.

Almeida, H., Campello, M., Weisbach, M., 2004. The cash flow sensitivity of cash. Journal of Finance 59, 1777-1804.

Baltensperger, E., 1978. Credit rationing: Issues and questions. Journal of Money, Credit and Banking 10, 170-183.

Bates, T., Kahle, K., Stulz, R., 2009. Why do u.s. firms hold so much more cash than they used to? Journal of Finance 64, 1985-2021.

Baumol, W., 1952. The transaction demand for cash: an inventory theoretical approach. Journal of Economics 66, 545-556.

Deloof, M., 2001. Intragroup relations and the determinants of corporate liquid reserves: Belgian evidence. European Financial Management 7, 375-392.

Denis, D., Sibilkov, V., 2010. Financial constraints, investment, and the value of cash holdings. Review of Financial Studies 23, 247-269.

Gitman, L., 1974. Corporate liquidity requirements: a simplified approach. The Financial Review 9, 7988. 
Graham, J., Harvey, C., 2001. The theory and practice of corporate finance: evidence from the field. Journal of Financial Economics 60, 187-243.

Grüner, J., Zoller, K., 1997. Computing partial expectaions from tables. Computing 59, 277-284.

Gryglewicz, S., 2011. A theory of corporate financial decisions with liquidity and solvency concerns. Journal of Financial Economics 99, 365-384.

Han, S., Qiu, J., 2007. Corporate precautionary cash holdings. Journal of Corporate Finance 13, 43-57.

Harford, J., 1999. Corporate cash reserves and acquisitions. Journal of Finance 54 (6), 1969-1997.

Harford, J., Mansi, S., Maxwell, W., 2008. Corporate governance and firm cash holding. Journal of Financial Economics 87, 535-555.

Holmström, B., Tirole, J., 1997. Financial intermediation, loanable funds, and the real sector. Quarterly Journal of Economics 112, 663-691.

Holmström, B., Tirole, J., 1998. Private and public supply of liquidity. Journal of Political Economy 106, 1-40.

Holmström, B., Tirole, J., 2000. Liquidity and risk management. Journal of Money, Credit and Banking 32, 295-319.

Jacobson, T., Schedvin, E., 2015. Trade credit and the propagation of corporate failure: An empirical analysis. Econometrica 83, 1315-1371. 
Jaffee, D., Modigliani, F., 1969. A theory and test of credit rationing. American Economic Review 59, 850-872.

Keynes, J., 1936. The general theory of employment. in: interest and money. Harcourt Brace, London.

Kieschnick, R., Laplante, M., Moussawi, R., 2013. Working capital management and shareholders' wealth. Review of Finance 17, 1827-1852.

Killmann, F., von Collani, E., 2001. A note on the convolution of the uniform and related distributions and their use in quality control. Economic Quality Control 16, 17-41.

Kling, G., Paul, S., Gonis, E., 2014. Cash holding, trade credit and access to shortterm bank finance. International Review of Financial Analysis 32, 123-131.

Landsman, Z., Valdez, E., 2005. Tail conditional expectations for exponential dispersion models. ASTIN Bulletin 35, 189-209.

Lins, K., Servaes, H., Tufano, P., 2010. What drives corporate liquidity? an international survey of cash holdings and lines of credit. Journal of Financial Economics 98, 160-176.

Miller, M., Orr, D., 1966. A model of the demand for money by firms. Quarterly Journal of Economics 80, 413-435.

Myers, S., 1977. Determinants of corporate borrowing. Journal of Financial Economics 5, 147-175. 
Myers, S., Majluf, N., 1984. Corporate financing and investment decisions when firms have information that investors do not have. Journal of Financial Economics $13,187-221$.

Richards, V., Laughlin, E., 1980. A cash conversion cycle approach to liquidity analysis. Financial Management 9, 32-38.

Riddick, L., Whited, T., 2009. The corporate propensity to save. Journal of Finance $64,1729-1766$.

Stiglitz, J., Weiss, A., 1981. Credit rationing in markets with imperfect information. American Economic Review 71, 393-410.

Sufi, A., 2009. Bank lines of credit in corporate finance: an empirical analysis. Review of Financial Studies 22, 1057-1088.

Tobin, J., 1980. Asset accumulation and economic activity. University of Chicago Press, Chicago.

Winkler, R., Roodman, G., Britney, R., 1972. The determination of partial moments. Management Science 19, 290-296.

Wolfson, M., 1996. A post keynesian theory of credit rationing. Journal of Post Keynesian Economics 18, 443-470.

Yun, H., 2009. The choice of corporate liquidity and corporate governance. Review of Financial Studies 22, 1447-1475. 
Figure 1: Model structure

\begin{tabular}{lll}
$\mathrm{t}=0$ & $\mathrm{t}=1$ & $\mathrm{t}=2$ \\
Start of CCC & Interim point & End of CCC \\
\hline Known parameters: & New information: & New information \\
$T, l, r, i$ and $L$ & actual $v=\operatorname{COS}_{1}-R E V_{1}$ & actual $k$ and $v$ \\
Net working capital: & $\underline{\text { Outcomes }:}$ & Outcomes: \\
$\tilde{w} \sim U(\underline{w}, \bar{w})$ & (a) $s+c \geq v$ & (a) $k<k^{*}$ \\
Cost-income ratio: & no liquidity problem & No insolvency \\
$\tilde{k} \sim U(0, \bar{k})$ & (b) $s+c<v$ & (b) $k \geq k^{*}$ \\
Debt holder: & liquidity default $\rightarrow \Theta$ & Insolvency
\end{tabular}

decides about $s$ for given $r$ expected insolvency risk $\pi$

Equity holder:

decides about $c$ for known $s$ expected cost-income ratio $E(\tilde{k})$

expected short-term liquidity need $E(\tilde{v})$ 
Figure 2: Average cash holding $(c)$, liquidity shortages (E shortage) and credit lines over time $(s)$

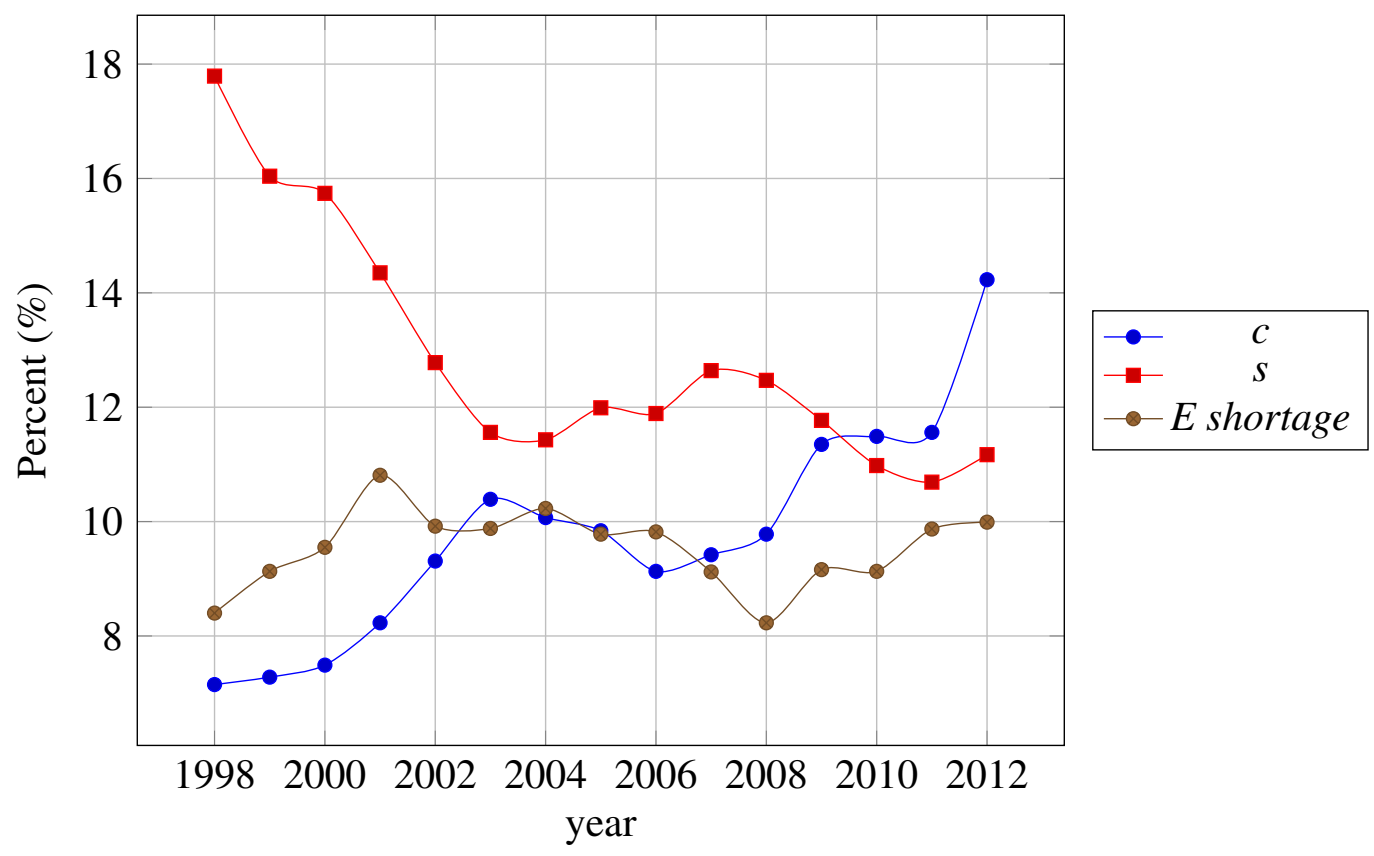

The figure depicts annual sample averages of cash ratios $(c)$ and credit lines $(s)$ in percent of total assets. It also shows the average expected liquidity shortage (E shortage). 
Table 2: Descriptive statistics

The sample includes all firm-year observations from 1998 to 2012. The variables contain cash ratios $(c)$, the expected return on investment (return), cost of debt $(r)$, the credit line $(s)$, the variation coefficient of the credit line $(v c s)$, expected liquidity shortage (E shortage), standard deviation of cash flows in industry (Sigma), market-to-book ratios, firm size, cash flows relative to assets (Cash flow assets), net working capital relative to assets (NWC assets), capital expenditure, leverage, $\mathrm{R} \& \mathrm{D}$ spending relative to sales ( $R D$ sales), dividend and acquisition dummies.

\begin{tabular}{lccccccc}
\hline \hline & mean & sd & p25 & p50 & p75 & min & max \\
\hline c & 0.10 & 0.10 & 0.03 & 0.07 & 0.14 & 0.00 & 0.48 \\
return & 0.11 & 0.05 & 0.07 & 0.10 & 0.14 & -0.07 & 0.28 \\
$\mathrm{r}$ & 0.08 & 0.12 & 0.05 & 0.06 & 0.08 & 0.00 & 1.00 \\
$\mathrm{r} 2$ & 0.02 & 0.11 & 0.00 & 0.00 & 0.01 & 0.00 & 1.01 \\
$\mathrm{~s}$ & 0.12 & 0.10 & 0.05 & 0.10 & 0.17 & 0.00 & 0.52 \\
vc s & 0.57 & 0.29 & 0.35 & 0.54 & 0.82 & 0.00 & 1.00 \\
E shortage & 0.09 & 0.14 & 0.00 & 0.01 & 0.13 & 0.00 & 0.50 \\
Sigma & 0.06 & 0.03 & 0.03 & 0.05 & 0.07 & 0.00 & 0.23 \\
Market to book & 4.07 & 4.05 & 1.86 & 2.91 & 4.55 & 0.52 & 27.68 \\
Size & 8.87 & 1.25 & 7.97 & 8.78 & 9.74 & 3.85 & 11.64 \\
Cash flow assets & 0.11 & 0.07 & 0.07 & 0.11 & 0.15 & -0.10 & 0.34 \\
NWC assets & 0.04 & 0.08 & 0.00 & 0.05 & 0.09 & -0.22 & 0.33 \\
CAPEX & 0.05 & 0.04 & 0.02 & 0.04 & 0.06 & 0.00 & 0.26 \\
Leverage & 0.23 & 0.14 & 0.13 & 0.22 & 0.32 & 0.00 & 0.64 \\
RD sales & 0.06 & 0.08 & 0.00 & 0.02 & 0.07 & 0.00 & 0.50 \\
DIV dummy & 0.67 & 0.47 & 0.00 & 1.00 & 1.00 & 0.00 & 1.00 \\
ACQ C & 0.00 & 0.00 & 0.00 & 0.00 & 0.00 & 0.00 & 0.02 \\
\hline \hline
\end{tabular}


Table 3: Standard models with fixed-effects

The sample includes all firm-year observations from 1998 to 2012. The models are estimated using OLS with fixed-effects. Standard errors are robust to clustering to account for heteroskedasticity and autocorrelation. The first model corresponds to the fixed-effects specification in Table III used in Bates et al. (2009). The second model refers to log cash ratios, and the third model explains the changes in cash ratios.

\begin{tabular}{llll}
\hline \hline & Cash/Assets & Log(Cash/Assets) & Changes \\
\hline Lag_dcash & & & $-0.061^{* *}$ \\
Lag_cash & & & $-0.443^{* * *}$ \\
Sigma & -0.008 & -0.541 & 0.043 \\
Market_to_book & $0.001^{*}$ & 0.008 & 0.000 \\
Size & $-0.016^{* * *}$ & -0.044 & $-0.010^{* * *}$ \\
Cash_flow_assets & $0.152^{* * *}$ & $1.431^{* * *}$ & $0.169^{* * *}$ \\
NWC_assets & $-0.273^{* * *}$ & $-2.614^{* * *}$ & $-0.136^{* * *}$ \\
CAPEX & $-0.430^{* * *}$ & $-3.985^{* * *}$ & $-0.312^{* * *}$ \\
Leverage & -0.020 & $-1.032^{* * *}$ & 0.023 \\
RD_sales & -0.005 & 0.511 & 0.036 \\
DIV_dummy & 0.002 & -0.036 & 0.001 \\
ACQ_C & $0.745^{* *}$ & $9.092^{* * *}$ & 0.012 \\
\hline r2_W & 0.068 & 0.066 & 0.317 \\
r2_b & 0.204 & 0.300 & 0.036 \\
r2_o & 0.153 & 0.221 & 0.165 \\
$N$ & 5405 & 5394 & 5280 \\
\hline \hline$* p<0.05,{ }^{* *} p<0.01,{ }^{* * *} p<0.001$ & &
\end{tabular}


Table 4: Models with Cash/Assets as depedent variable

The sample includes all firm-year observations from 1998 to 2012. The models are estimated using OLS with fixed-effects. Standard errors are robust to clustering to account for heteroskedasticity and autocorrelation. In line with model one in Table 2, the cash ratio is the dependent variable. Based on theoretical considerations, the expected return on investment (return), cost of debt $(r)$, the credit line $(s)$, the variation coefficient of the credit line ( $v c s)$, and expected liquidity shortage (E shortage) act as additional explanatory variables.

\begin{tabular}{lllllll}
\hline \hline & \multicolumn{1}{c}{$[\mathrm{A} 1]$} & {$[\mathrm{B} 1]$} & {$[\mathrm{C} 1]$} & {$[\mathrm{D} 1]$} & {$[\mathrm{E} 1]$} & {$[\mathrm{F} 1]$} \\
\hline return & 0.025 & -0.058 & & & & \\
r & 0.001 & & -0.003 & & & \\
s & $-0.138^{* * * *}$ & & & $-0.130^{* * *}$ & & \\
vc_s & 0.011 & & & & 0.002 & \\
E_shortage & -0.014 & & & & & 0.023 \\
Sigma & 0.005 & -0.028 & -0.018 & 0.008 & -0.002 & 0.007 \\
Market_to_book & 0.001 & $0.001^{*}$ & $0.001^{*}$ & 0.001 & $0.001^{*}$ & 0.001 \\
Size & $-0.009^{*}$ & $-0.015^{* * *}$ & -0.008 & $-0.020^{* * *}$ & $-0.020^{* * *}$ & $-0.019^{* * *}$ \\
Cash_flow_assets & $0.170^{* * *}$ & $0.169^{* * *}$ & $0.170^{* * *}$ & $0.149^{* * *}$ & $0.148^{* * *}$ & $0.129^{* * *}$ \\
NWC_assets & $-0.172^{* *}$ & $-0.245^{* * *}$ & $-0.228^{* * *}$ & $-0.267^{* * *}$ & $-0.283^{* * *}$ & $-0.295^{* * *}$ \\
CAPEX & $-0.396^{* * *}$ & $-0.396^{* * *}$ & $-0.392^{* * *}$ & $-0.428^{* * *}$ & $-0.451^{* * *}$ & $-0.442^{* * *}$ \\
Leverage & -0.011 & -0.020 & -0.036 & 0.005 & -0.006 & -0.007 \\
RD_sales & -0.078 & -0.037 & 0.007 & -0.051 & -0.014 & -0.061 \\
DIV_dummy & 0.005 & 0.001 & 0.000 & 0.002 & 0.007 & 0.008 \\
ACQ_C & $0.778^{* *}$ & $0.744^{* *}$ & $0.659^{*}$ & $0.883^{* *}$ & $0.877^{* *}$ & $0.748^{* *}$ \\
\hline r2_W & 0.086 & 0.062 & 0.064 & 0.087 & 0.072 & 0.071 \\
r2_b & 0.125 & 0.177 & 0.229 & 0.180 & 0.153 & 0.100 \\
r2_o & 0.109 & 0.131 & 0.147 & 0.156 & 0.133 & 0.090 \\
$N$ & 3053 & 5344 & 4487 & 3809 & 4472 & 3665 \\
\hline \hline${ }^{*} p<0.05,{ }^{* *} p<0.01,{ }^{* * *} p<0.001$ & & & & \\
\hline
\end{tabular}


Table 5: Models with Log(Cash/Assets) as dependent variable

The sample includes all firm-year observations from 1998 to 2012. The models are estimated using OLS with fixed-effects. Standard errors are robust to clustering to account for heteroskedasticity and autocorrelation. In line with model two in Table 2, the log cash ratio is the dependent variable. Based on theoretical considerations, the expected return on investment (return), cost of debt $(r)$, the credit line $(s)$, the variation coefficient of the credit line ( $v c$ $s$ ), and expected liquidity shortage ( $E$ shortage) act as additional explanatory variables.

\begin{tabular}{|c|c|c|c|c|c|c|}
\hline & [A2] & [B2] & [C2] & [D2] & $\overline{\text { [E2] }}$ & [F2] \\
\hline return & 0.024 & $-0.945^{* *}$ & & & & \\
\hline $\mathrm{r}$ & -0.006 & & -0.019 & & & \\
\hline $\mathrm{s}$ & $-2.013^{* * *}$ & & & $-1.704^{* * *}$ & & \\
\hline vc_s & 0.058 & & & & -0.008 & \\
\hline E_shortage & -0.372 & & & & & 0.141 \\
\hline Sigma & -0.037 & -0.622 & -0.643 & -0.350 & -0.321 & -0.314 \\
\hline Market_to_book & 0.006 & 0.008 & 0.011 & 0.005 & $0.010^{*}$ & 0.004 \\
\hline Size & -0.025 & -0.029 & 0.024 & -0.082 & -0.061 & -0.042 \\
\hline Cash_flow_assets & $1.865^{* * *}$ & $1.647^{* * *}$ & $1.654^{* * *}$ & $1.642^{* * *}$ & $1.421^{* * *}$ & $1.523^{* * *}$ \\
\hline NWC_assets & $-1.839^{* * *}$ & $-2.434^{* * *}$ & $-2.569^{* * *}$ & $-2.253^{* * *}$ & $-2.544^{* * *}$ & $-2.619^{* * *}$ \\
\hline CAPEX & $-4.326^{* * *}$ & $-3.555^{* * *}$ & $-4.131^{* * *}$ & $-3.843^{* * *}$ & $-4.054^{* * *}$ & $-4.233^{* * *}$ \\
\hline Leverage & $-0.934^{* * *}$ & $-1.075^{* * *}$ & $-1.301^{* * *}$ & $-0.739^{* *}$ & $-0.797^{* * *}$ & $-0.949^{* * *}$ \\
\hline RD_sales & 0.440 & 0.175 & 0.542 & 0.580 & 0.637 & 0.687 \\
\hline DIV_dummy & 0.000 & -0.034 & -0.084 & -0.001 & 0.028 & 0.024 \\
\hline ACQ_C & $9.437^{* * *}$ & $9.307^{* * *}$ & $9.150^{* * *}$ & $9.368^{* * *}$ & $9.264^{* * *}$ & $8.696^{* * *}$ \\
\hline $\mathrm{r} 2 \_\mathrm{w}$ & 0.095 & 0.066 & 0.077 & 0.087 & 0.056 & 0.063 \\
\hline r2_b & 0.244 & 0.272 & 0.272 & 0.299 & 0.257 & 0.240 \\
\hline r2_o & 0.188 & 0.200 & 0.178 & 0.243 & 0.201 & 0.198 \\
\hline$N$ & 3048 & 5333 & 4476 & 3804 & 4466 & 3660 \\
\hline
\end{tabular}


Table 6: Models with change in cash ratios as dependent variable

The sample includes all firm-year observations from 1998 to 2012. The models are estimated using OLS with fixed-effects. Standard errors are robust to clustering to account for heteroskedasticity and autocorrelation. In line with model three in Table 2, the change in cash ratio is the dependent variable. Based on theoretical considerations, the expected return on investment (return), cost of debt $(r)$, the credit line $(s)$, the variation coefficient of the credit line ( $v c s$ ), and expected liquidity shortage ( $E$ shortage) act as additional explanatory variables.

\begin{tabular}{lllllll}
\hline \hline & {$[\mathrm{A} 3]$} & {$[\mathrm{B} 3]$} & {$[\mathrm{C} 3]$} & {$[\mathrm{D} 3]$} & {$[\mathrm{E} 3]$} & {$[\mathrm{F} 3]$} \\
\hline return & -0.032 & $-0.102^{* *}$ & & & & \\
$\mathrm{r}$ & 0.007 & & -0.001 & & & \\
$\mathrm{~S}$ & $-0.098^{* * *}$ & & & $-0.086^{* * *}$ & & \\
vc_s & 0.000 & & & & -0.002 & \\
E_shortage & -0.025 & & & & & 0.003 \\
Sigma & 0.071 & 0.049 & 0.060 & 0.034 & 0.027 & 0.035 \\
Market_to_book & 0.000 & 0.000 & 0.001 & -0.000 & 0.000 & -0.000 \\
Size & $-0.009^{* *}$ & $-0.008^{* * *}$ & $-0.007^{* *}$ & $-0.016^{* * *}$ & $-0.012^{* * *}$ & $-0.014^{* * *}$ \\
Cash_flow_assets & $0.192^{* * *}$ & $0.192^{* * *}$ & $0.168^{* * *}$ & $0.168^{* * *}$ & $0.169^{* * *}$ & $0.154^{* * *}$ \\
NWC_assets & $-0.091^{*}$ & $-0.121^{* * *}$ & $-0.134^{* * *}$ & $-0.132^{* * *}$ & $-0.143^{* * *}$ & $-0.151^{* * *}$ \\
CAPEX & $-0.317^{* * *}$ & $-0.276^{* * *}$ & $-0.306^{* * *}$ & $-0.329^{* * *}$ & $-0.324^{* * *}$ & $-0.333^{* * *}$ \\
Leverage & 0.020 & 0.021 & 0.008 & $0.034^{*}$ & 0.032 & 0.025 \\
RD_sales & -0.031 & 0.007 & 0.032 & -0.019 & 0.018 & -0.018 \\
DIV_dummy & 0.002 & 0.001 & -0.001 & -0.000 & 0.003 & 0.003 \\
ACQ_C & 0.456 & 0.065 & 0.210 & 0.272 & 0.177 & 0.254 \\
\hline r2_W & 0.376 & 0.316 & 0.335 & 0.345 & 0.325 & 0.339 \\
r2_b & 0.005 & 0.039 & 0.011 & 0.001 & 0.007 & 0.000 \\
r2_o & 0.112 & 0.164 & 0.154 & 0.122 & 0.147 & 0.115 \\
$N$ & 3011 & 5278 & 4424 & 3717 & 4367 & 3573 \\
\hline \hline
\end{tabular}

${ }^{*} p<0.05,{ }^{* *} p<0.01,{ }^{* * *} p<0.001$ 


\section{Appendix A. Theorem 1}

Proof. We differentiate equation (2) with respect to $c$ and obtain the first-order condition (FOC).

$$
\begin{aligned}
\frac{d U_{E}(c)}{d c} & =-T(1-k)+l+r \int_{c}^{\bar{v}} \frac{v-c}{\bar{w}-\underline{w}} d v-(1-c) r \int_{c}^{\bar{v}} \frac{-1}{\bar{w}-\underline{w}} d v=0 \\
& -T(1-k)+l+\frac{r}{\bar{w}-\underline{w}} \int_{c}^{\bar{v}}(v-2 c+1) d v=0 \\
& -T(1-k)+l+\frac{r}{\bar{w}-\underline{w}}\left[\frac{1}{2} \bar{v}^{2}-2 c \bar{v}+\bar{v}-\frac{1}{2} c^{2}+2 c^{2}-c\right]=0 \\
& \frac{3}{2} c^{2}-(1+2 \bar{v}) c+\frac{1}{2} \bar{v}^{2}+\bar{v}-\frac{(T(1-k)-l)(\bar{w}-\underline{w})}{r}=0
\end{aligned}
$$

If a liquidity need can arise, i.e. $\bar{v}=\bar{w}-T(1-k)>0$, there will be one optimal value of cash holding maximizing $U_{E}(c)$. To see that, note that the FOC is a $\mathrm{U}$-shaped parabola and that the second-order condition implies $c<\frac{1+2 \bar{y}}{3}$ to ensure a maximum, suggesting that the maximizer is the smaller root of the FOC. Hence, we can state the maximizer, labeled $c_{T}^{*}$.

$$
\begin{aligned}
c_{T}^{*} & =\frac{1+2 \bar{v}-\sqrt{1+4 \bar{v}+4 \bar{v}^{2}-3 \bar{v}^{2}-6 \bar{v}+\frac{6}{r}(T(1-k)-l)(\bar{w}-\underline{w})}}{3} \\
& =\frac{1+2 \bar{v}-\sqrt{1-2 \bar{v}+\bar{v}^{2}+\frac{6}{r}(T(1-k)-l)(\bar{w}-\underline{w})}}{3} \\
& =\frac{1+2 \bar{v}-\sqrt{(1-\bar{v})^{2}+\frac{6}{r}(T(1-k)-l)(\bar{w}-\underline{w})}}{3}
\end{aligned}
$$


To ensure that firms hold transaction cash, i.e. $\left.\frac{d U_{E}(c)}{d c}\right|_{c=0}>0$, the following inequality has to hold.

$$
r>\frac{(T(1-k)-l)(\bar{w}-\underline{w})}{\frac{1}{2} \bar{v}^{2}+\bar{v}}
$$

\section{Appendix B. Lemma 3}

Proof. Based on Lemma 2, we simplify the critical cost-income ratio focusing on terms involving $c$, where $A$ refers to terms independent from $c$.

$$
k^{*}=A+\frac{1-L(1+i)}{(1-c) T}+\frac{r c s}{(\bar{w}-\underline{w}) T^{2} \bar{k}}
$$

Then we determine $\frac{\partial k^{*}}{\partial c}$, i.e. the partial impact of cash holding on the critical cost-income ratio.

$$
\begin{aligned}
\frac{\partial k^{*}}{\partial c} & =-\frac{1-L(1+i)}{T(1-c)^{2}}(-1)+\frac{r s}{(\bar{w}-\underline{w}) T^{2} \bar{k}} \\
& =\frac{1-L(1+i)}{T(1-c)^{2}}+\frac{r s}{(\bar{w}-\underline{w}) T^{2} \bar{k}}
\end{aligned}
$$

To ensure that $\frac{\partial k^{*}}{\partial c}>0$, financial leverage needs to be below a critical level, 
$L_{\text {max }}$

$$
\begin{aligned}
\frac{1-L(1+i)}{T(1-c)^{2}}+\frac{r s}{(\bar{w}-\underline{w}) T^{2} \bar{k}} & >0 \\
1-L(1+i) & >-\frac{r s(1-c)^{2}}{(\bar{w}-\underline{w}) T \bar{k}} \\
L & <\frac{1}{1+i}+\frac{r s(1-c)^{2}}{(\bar{w}-\underline{w}) T \bar{k}(1+i)}=L_{\max }
\end{aligned}
$$

\section{Appendix C. Theorem 2}

Proof. Equation (5) can be simplified using (3) and setting $\Theta=0$ without loss of generality.

$$
\begin{aligned}
U_{E}(c) & =\left[(1-c) T\left(1-\frac{\bar{k}}{2}\right)-L(1+i)+1-l+l c\right]\left[1-\int_{s+c}^{\bar{w}-T+T \bar{k}} f_{v}(\tilde{v}) d v\right] \\
& -(1-c) r \frac{-\frac{1}{2} s^{2}-c s+\bar{w} s-T(1-\bar{k}) s}{(\bar{w}-\underline{w}) T \bar{k}}
\end{aligned}
$$


Then we evaluate the probability of liquidity default $\int_{s+c}^{\bar{w}-T+T \bar{k}} f_{v}(\tilde{v}) d v$.

$$
\begin{aligned}
\int_{s+c}^{\bar{w}-T+T \bar{k}} f_{v}(\tilde{v}) d v & =\left[\frac{-\frac{1}{2} v^{2}+(\bar{w}-T+T \bar{k}) v}{(\bar{w}-\underline{w}) T \bar{k}}\right]_{s+c}^{\bar{w}-T+T \bar{k}} \\
& =\frac{1}{(\bar{w}-\underline{w}) T \bar{k}}\left[\frac{1}{2}(\bar{w}-T+T \bar{k})^{2}-(\bar{w}-T+T \bar{k})(s+c)+\frac{1}{2}(s+c)^{2}\right] \\
& =\frac{(\bar{w}-T+T \bar{k}-s-c)^{2}}{2(\bar{w}-\underline{w}) T \bar{k}}
\end{aligned}
$$

Using (C.2) in (C.1) and noting that $(\bar{w}-\underline{w}) T \bar{k}$ is a constant.

$$
\begin{aligned}
U_{E}(c) & =\left[(1-c) T\left(1-\frac{\bar{k}}{2}\right)-L(1+i)+1-l+l c\right]\left[1-\frac{(\bar{w}-T+T \bar{k}-s-c)^{2}}{2(\bar{w}-\underline{w}) T \bar{k}}\right] \\
& -(1-c) r \frac{-\frac{1}{2} s^{2}-c s+\bar{w} s-T(1-\bar{k}) s}{(\bar{w}-\underline{w}) T \bar{k}} \\
& \propto\left[(1-c) T\left(1-\frac{\bar{k}}{2}\right)-L(1+i)+1-l+l c\right]\left[(\bar{w}-\underline{w}) T \bar{k}-\frac{1}{2}(\bar{w}-T+T \bar{k}-s-c)^{2}\right] \\
& -(1-c) r s\left(\bar{w}-T+T \bar{k}-\frac{1}{2} s-c\right)
\end{aligned}
$$

Using $\bar{v}=\bar{w}-T+T \bar{k}$, we finally obtain

$$
\begin{aligned}
U_{E}(c) & \propto\left[(1-c) T\left(1-\frac{\bar{k}}{2}\right)-L(1+i)+1-l+l c\right]\left[(\bar{w}-\underline{w}) T \bar{k}-\frac{1}{2}(\bar{v}-s-c)^{2}\right] \\
& -(1-c) r s\left(\bar{v}-\frac{1}{2} s-c\right)
\end{aligned}
$$


Next, we derive the FOC.

$$
\begin{aligned}
\frac{d U_{E}(c)}{d c} & =\left[-T\left(1-\frac{\bar{k}}{2}\right)+l\right]\left[(\bar{w}-\underline{w}) T \bar{k}-\frac{1}{2}(\bar{v}-s-c)^{2}\right] \\
& +\left[(1-c) T\left(1-\frac{\bar{k}}{2}\right)-L(1+i)+1-l+l c\right](\bar{v}-s-c) \\
& +r s\left(\bar{v}-\frac{1}{2} s-c\right)+(1-c) r s=0
\end{aligned}
$$

To simplify the FOC, we introduce three constants that depend on model parameters but do not depend on $c$ and $s$ so that $\alpha=T\left(1-\frac{\bar{k}}{2}\right)-l>0$, $\beta=(\bar{w}-\underline{w}) T \bar{k}>0$ and $\gamma=1-L(1+i)>0$.

$$
\begin{aligned}
\frac{d U_{E}(c)}{d c} & =-\alpha\left[\beta-\frac{1}{2}(\bar{v}-s-c)^{2}\right] \\
& +[(1-c) \alpha+\gamma](\bar{v}-s-c) \\
& +r s\left(\bar{v}-\frac{1}{2} s-c\right)+(1-c) r s=0
\end{aligned}
$$

So that

$$
\begin{aligned}
\frac{d U_{E}(c)}{d c} & =-\alpha \beta+\frac{\alpha}{2}\left((\bar{v}-s)^{2}-2(\bar{v}-s) c+c^{2}\right) \\
& +(1-c) \alpha(\bar{v}-s-c)+\gamma(\bar{v}-s-c) \\
& +r s\left(\bar{v}-\frac{1}{2} s+1\right)-2 r s c=0
\end{aligned}
$$


Then

$$
\begin{aligned}
\frac{d U_{E}(c)}{d c} & =-\alpha \beta+\frac{\alpha}{2}(\bar{v}-s)^{2}-\alpha(\bar{v}-s) c+\frac{\alpha}{2} c^{2} \\
& +\alpha(\bar{v}-s)-\alpha c-\alpha(\bar{v}-s) c+\alpha c^{2} \\
& +\gamma(\bar{v}-s)-\gamma c-2 r s c+r s\left(\bar{v}-\frac{1}{2} s+1\right)=0
\end{aligned}
$$

Finally we obtain

$$
\begin{aligned}
\frac{d U_{E}(c)}{d c} & =\frac{3}{2} \alpha c^{2}-(2 \alpha(\bar{v}-s)+\alpha+\gamma+2 r s) c \\
& +\frac{\alpha}{2}(\bar{v}-s)^{2}+(\bar{v}-s)(\alpha+\gamma)+r s\left(\bar{v}-\frac{1}{2} s+1\right)-\alpha \beta=0
\end{aligned}
$$

The second-order condition determines an upper bound for optimal cash holding to ensure that a maximum is reached.

$$
\begin{gathered}
\frac{d^{2} U_{E}(c)}{d c^{2}}=3 \alpha c-(2 \alpha(\bar{v}-s)+\alpha+\gamma+2 r s)<0 \\
\Leftrightarrow c<\frac{2 \alpha(\bar{v}-s)+\alpha+\gamma+2 r s}{3 \alpha}=c_{u p}
\end{gathered}
$$

Accordingly, optimal cash holding based on the precaution motive, $c_{P}^{*}$ is the smaller root of the FOC. Therefore, there is at most one $c_{P}^{*} \in\left[0, c_{u p}\right]$ that maximizes $U_{E}(c)$. Using $\Omega=\frac{\alpha}{2}(\bar{v}-s)^{2}+(\bar{v}-s)(\alpha+\gamma)+r s\left(\bar{v}-\frac{1}{2} s+1\right)-\alpha \beta>0$ for 
the term that does not depend on $c$, we obtain the maximizer $c_{P}^{*}$.

$$
c_{P}^{*}=\frac{2 \alpha(\bar{v}-s)+\alpha+\gamma+2 r s-\sqrt{(2 \alpha(\bar{v}-s)+\alpha+\gamma+2 r s)^{2}-6 \alpha \Omega}}{3 \alpha}
$$

It is easy to see that $c_{P}^{*}>0$, which is not guaranteed for transaction cash $c_{T}^{*}$ only if the interest rate on short-term finance is in a permitted range (see Theorem 1). To ensure that a solution exists, the following condition has to hold $(2 \alpha(\bar{v}-s)+\alpha+\gamma+2 r s)^{2}-6 \alpha \Omega \geq 0$.

\section{Appendix D. Theorem 3}

Proof. Credit rationing does not occur (i.e. $s^{*}=\bar{s}>\bar{z}$ ) if and only if condition (7)

holds. The RHS of (7) depends on $r$, since $\pi(r)$ with $\frac{\partial \pi}{\partial r}>0$. We regard (7) as a simple fixed-point iteration with $r_{n+1}=g\left(r_{n}\right)(n=1,2, \ldots)$, where $g(r)=\frac{\pi(r)(1-\epsilon)}{1-\pi(r)}$. Starting the iteration with the lowest possible value $r_{0}=r_{f}=0$ and, as long as $\pi\left(r_{0}\right)>0 \Rightarrow r_{1}<g\left(r_{0}\right), r$ has to increase so that (7) holds. Increasing the LHS of (7) also increases the RHS of (7). To insure that (7) holds, the marginal change on the LHS has to outweigh the marginal change on the RHS. This is an application of the contraction mapping theorem, and if $g^{\prime}(r)>1, g(r)$ is not a contraction 
mapping and hence (7) does not hold.

$$
\begin{aligned}
g^{\prime}(r) & =\frac{\frac{\partial \pi}{\partial r}(1-\epsilon)(1-\pi)+\frac{\partial \pi}{\partial r} \pi(1-\epsilon)}{(1-\pi)^{2}}>1 \\
\Leftrightarrow & \frac{\partial \pi}{\partial r}>\frac{(1-\pi)^{2}}{1-\epsilon}
\end{aligned}
$$

$\frac{\partial \pi}{\partial r}$ follows from Lemma 2 and (4) with $c=0$ as $r<r_{\text {min }}$ and $s=\bar{v}$ as there is no credit rationing. In addition, the partial expected value for the short-term liquidity need is positive and can be written as follows.

$$
\int_{c}^{s+c}(v-c) f_{v}(v) d v=\int_{0}^{\bar{v}} v f_{v}(v) d v=E_{0}^{\bar{v}}(\tilde{v})>0
$$

Hence, the partial impact of $r$ on the critical cost-income ratio is

$$
\frac{\partial k^{*}}{\partial r}=-\frac{1}{T} E_{0}^{\bar{v}}(\tilde{v})<0
$$

Then we obtain $\frac{d \pi}{\partial r}$.

$$
\frac{\partial \pi}{\partial r}=-\frac{\partial k^{*}}{\partial r} \frac{1}{\bar{k}}=\frac{E_{0}^{\bar{v}}(\tilde{v})}{T \bar{k}}>0
$$

Hence

$$
\frac{E_{0}^{\bar{\nu}}(\tilde{v})}{T \bar{k}}>\frac{(1-\pi)^{2}}{1-\epsilon}
$$

